\title{
Nurse's Perception of Student Clinical Competence in the Emergency Nursing Section of Universitas Muhammadiyah Yogyakarta Indonesia
}

\author{
$1^{\text {st }}$ Nur Chayati \\ School of Nursing, Faculty of Medicine \\ and Health Science \\ Universitas Muhammadiyah \\ Yogyakarta \\ Yogyakarta, Indonesia \\ nchayati1983@gmail.com
}

\author{
$2^{\text {nd }}$ Arianti \\ School of Nursing, Faculty of Medicine \\ and Health Science \\ Universitas Muhammadiyah \\ Yogyakarta \\ Yogyakarta, Indonesia \\ ariimoon@gmail.com
}

\author{
$3^{\text {rd }}$ Azizah Khoiriyati \\ School of Nursing, Faculty of Medicine \\ and Health Science \\ Universitas Muhammadiyah \\ Yogyakarta \\ azizahkhoiriyati@yahoo.com
}

\begin{abstract}
Professional education has its own challenges in providing clinical learning experiences for students. One of the challenges is integrating theory and practice. The role of the preceptor is very important to bridge this integration so that students can achieve competencies as expected. The purpose of this study is to explore the perceptions of the clinical preceptor of the emergency nursing regarding clinical experience in guiding students to achieve competency in the emergency nursing. This research is a qualitative study of phenomenology. The participants in this study were 7 clinical preceptors in the department of emergency care at UMY nursing study program education hospital which included PKU Muhammadiyah Hospital in Yogyakarta, PKU Muhammadiyah Gamping Hospital, and PKU Muhammadiyah Hospital in Temanggung. The Data retrieval using semi-structured interview techniques. Data analysis using content analysis with open Code software. The results of this study found one main theme, that is the strategy and learning reinforcement consisting of two themes for the realm of knowledge, two themes for the realm of skills and three themes for the realm of attitude. There is should be a strategy and learning and mentoring reinforcement at the professional level in the knowledge, skills and attitudes realm.
\end{abstract}

Keywords- nursing student competence, emergency clinical rotation, clinical preceptor, perception

\section{INTRODUCTION}

The professional level education at the bachelor nursing program in Indonesia presents its own challenges in providing clinical learning experiences to preceptees/clinical practice students. There are still many assumptions that bachelor of nursing graduates are less competent than diploma of nursing graduates [1]. Hence, the task of preceptees during their professional education is how to integrate theory and practice, to provide quality care to patients [2. The role of the clinical preceptor/supervisor is very important in the integration process so the preceptees become more competent and confident after they graduated [3].

In the case of Universitas Muhammadiyah Yogyakarta (UMY), bachelor of nursing students will carry out clinical practice for 9.5 months on 9 sections in the hospital, including the emergency nursing section. The basic competency of an emergency nursing is the nurses' ability to carry out their work supported by general and specific knowledge that reflects their competence and attitude, including their professional and social values [4].

Furthermore, the six general emergency nurses' competencies include patient caring, medical knowledge, learning and self improvement based on practical experience, communication and interpersonal skills, and professionalism and system based practice [5]. The six competencies are supported by 56 attitudes or

behaviors that can identify the job satisfaction level in the emergency nursing, through three main strategies that reflect the profile of emergency nurses namely operational excellent , patient-focused approach, and meaningful assistance in service delivery [5].

The Nursing Study Bachelor Program of UMY has established competencies for practical students in the emergency nursing, which include knowledge, skills and attitude competencies. However, these competencies have never been asked the users/stakeholders about their opinions and evaluations. The evaluation that has been carried out is a quantitative evaluation through the logbook and the final examination phase. Nevertheless, the evaluation has not been able to describe the achievements in three domains of clinical competence and to answer the competency urgency for the students' work in the future.

\section{METHOD}

This research is a qualitative study with a phenomenological approach. The participants that involved in here were 7 clinical preceptors. This study used purposive sampling in the Department of Emergency Nursing at Nursing Study Bachelor Program UMY education hospital, which included PKU Muhammadiyah Hospital in Yogyakarta, PKU Muhammadiyah Gamping Hospital, and PKU Muhammadiyah Hospital in Temanggung. The data retriaval used in-depth interview techniques with semistructured questions in February 2018. This data corroborated with Focus Group Discussion data which conducted three times on students/preceptees. 


\section{RESULT}

The results of this study have identified 7 themes, namely (1) the concept and problem analysis strengthening, (2) the suitability between cases and levels of knowledge, (3) the motivation support for action, (4) the sufficient competency skills with various alternative learning systems, (5) the leadership and spirituality, (6) the caring action, and (7) the efforts to improve the affective quality of students (see Table 1.1).

\section{A. The concepts and problem analysis strengthening}

This theme is supported by two sub-themes, namely the lack of knowledge when entering the initial phase and the concept and problem analysis strengthening.

1) The Lack of knowledge when entering the initial phase

The knowledge mastering and clinical reasoning preceptees abilities in the emergency care department at the beginning of the phase still varied. The knowledges that have been assessed is less related to the basic nursing sciences such as cardiac anatomy and electrocardiography. Here is one excerpt from the interview:

"... because in the emergency room I am the one who accompanied every day, I can feel more about the efforts of students, especially when in the emergency nursing action. In my opinion, the emergency situation was still lack,. Which has been still carried over by the situation in the room where the patient was not an emergency patient ...". (Informant 6)

\section{2) The concepts and problem analysis strengthening}

The reinforcement of concepts and its reflection need to be done before entering the emergency room especially patient management strategies, as to improve the students' ability to analyze problems. Here are some interview excerpts:

"It is possible that this emergency department is rarely found in the other stations. For example, getting a patient with the situation of diabetic ketoacidosis is very rare, we get it in other stations and then various types of trauma, such as various types of trauma. Now, the only thing that should to be strengthened is related to the knowledge is might be a trick to handle it. " (Informant 6).

\section{B. The suitability of case and level of knowledge}

This theme is supported by two sub-themes, namely the sufficient number of cases and the level of knowledge for generalist nurses.

\section{1) The number of cases is sufficient}

Many cases have been obtained by students such as resuscitation and cardiac cases with decreased consciousness. Another cases that identified as the rare cases also have been obtained, such as patients with CVC and patients with mechanical ventilation.

"... I think the achievement gained enough because there were a lot of cases in the Emergency Room (ER)." We actually have quite a lot of cases because in around 2 or 3 days there must be a patient for resuscitation. " (Informant 1).
2) The level of knowledge is suitable for a bachelor degree

According to the preceptors, the students' knowledge are generally good. This could be seen during pre-conferences, case discussions and tutorials. The students have able to explain the pathway of the case that managed in detail and in-depth discussion. There was an attempt to apply the concept to practice. This level of knowledge is quite suitable for generalists.

"... they are really ready to face. So, if this is asked, they could answered, like the pathway problem. In detail ..." (Informant 3)

"... in my opinion, from the questions that were often asked on pre-conference, or in the discussions, is quite good. There is a few students that might still be lack. But overall they are knowledgeable. Alhamdulillah, if I see it's good ". (Informant 3)

\section{Motivational support for action}

This theme is supported by two sub-themes. These are the students who are not brave enough to act and the students who need motivation to try.

1) The students who not brave enough to act

According to the supervisor/preceptor, the students that are not brave enough to take action when the patient arrives, especially if the case was severe, seems to be passive. When the students involved in handling resuscitation, they only lasted for a short time. For example at the pulmonary heart resuscitation, they preferred to take a triage. Some of the skills that were both invasive and non-invasive appeared to lack confidence when it should be performed. In the other case, the analyzing ability still needs to be improved either.

"... sometimes there are many students who are afraid like what I said before. What we really want is this: the red zone resuscitation ..." (Informant 1)

\section{2) The students who need motivation to try}

The students must be motivated, reminded and educated before handling patients. Therefore the students picket schedule should be adjusted to the preceptor's picket schedule. The preceptor also must explore and approach students who take a passive action.

".... there is a kind of education, reinforcement for, both for the preceptees and for the patient" (Informant 6)

"The students should always be reminded. If it possible, the students' work schedule, should be adjusted to the preceptor. It will be ideal ". (Informant 2)

\section{The sufficient competency skills with various alternative learning systems}

This theme is supported by two sub-themes, namely the alternative learning systems for skills that have not been reached, and the sufficient types of skills.

1) The alternative learning systems for skills that have not yet been achieved

The preceptor said that the skills that must be achieved by students should be assessed according to the level of difficulty or psychomotor level. It could be by only mastering the concept, seeing and trying under the 
supervising or independently. The difficult skills should only reach level 1 (mastering theoretical concepts) and 2 (seeing) such as mechanical ventilation and arterial blood sampling. To meet the target skill that must be achieved, some types of skills that are difficult to find when practiced could be tricked by using pictures.

"But usually I anticipate by draw it. It should be a patient indeed. But because there wasn't available, I choose an image or maybe another skill " (Informant 2)

\section{2) The sufficient type of skill}

The basic skills in the emergency nursing that must be achieved by students considered sufficiently. It could be seen when the students could obtain several types of skills such as resuscitation, tracheostomy care, hemodynamic monitoring and airway management. When the students got one managed patient they have to analyzed, they could applied their basic and advance skills.

"In the ICU, there are many skills that should be mastered, such as the hemodynamic monitoring and the GCS measurements, performing 12 lead ECGs, suctioning then bathing patients in bed, treating mechanical ventilation, treating patients with mechanical ventilation then oral hygiene, ET care, tracheostomy care, CVP measurement if there is a patient fit who install CVP, . If the intubation and the defibrillation, the students just have to see. Another skills that sould be mastered are dressing infusion then injection, IV injection, IM, SC, then wound care. ... (Informant 3)

\section{E. Leadership and spirituality}

This theme is supported by three sub-themes; the easiness to get along with colleagues, the cooperation, the leadership and the spirituality that should be maintained.

\section{1) The easiness to get along with colleagues}

The UMY nursing students are considered to be sociable which it shown by the students' characteristics whose friendly, easy to blend in and have a good relationship with another nurses in the work room. This is the following quote from the informant:

"...They are also quite friendly. They are easy to blend in and are also quite polite ". (Informant 3)

\section{2) The Collaboration and The Leadership}

Some of the leadership abilities of the students are already good, but some are still seem lack. The students' ability of cooperation is considered quite good either. This is a following quote from the informant:

"... the leadership is still lack ..." (informant 2)

"... leadership has no problem, ma'am ..." (Informant 3)

"So the cooperation with us is quite good." (Informant 6)

\section{3) The Maintained Spirituality Aspect}

Each of the students should be able to teach tayamum and pray to the patients. Furthermore, each male student should have to pray at the mosque when the adhan has echoed, while the female students took turns to pray at the mosque after the male students have finished. In the other case, the female students have worn professional uniform by the Islamic shari'a properly.
"... like teaching for tayamum and prayers this is also already .... If the Islamic behavior, the son is God willing, every Adhan and when it is safe, they ask for permission to pray at the mosque ... if from the performance of the way The princess is actually wearing a syari yes. .... "(Informant 3).

\section{F. The Caring Action}

This theme is supported by three sub-themes, namely the emphasis on spiritual intervention, the situation response, and the empathy and the honesty.

1) The emphasis on spiritual intervention

The students have not fully intervened spiritual aspect into the patients, for example they forgot to say salam when they met the patients and forgot to guide patients to pray.

"... they still be lack by did not greet patients with salam. Another skills that were lack, if I am not mistaken, when they often forgot to guide the prayer patients ..." (Informant 5)

2) The situation Response

Some of the students' discipline and caring action for the patients seem to lack.

"Not all of the students are care enough to the the patients. Actually, there are students which have been caring the patients properly. But there are also some students who be ignorant." (Informant 3)

\section{3) cEmpathy and honest}

The attitude of students is good, polite and respectful, both to the patients and to their nurse colleagues. In addition, the students empathy and concern still varied.

"... In the emergency room I think the attitude is good huh. ... because in the emergency room we emphasized from the beginning that there was nothing to say. ... So ... when they want to have an interest they call first or wa ". (Informant 1)

\section{G. The Efforts to improve the affective quality of the students}

This theme is supported by two sub-themes: the standardization of judgment and attitude and the character accompaniment strategies.

a. The standardization of judgment and attitude

The students grade are generally in the good category. What needs to be improved is that the assessment criteria in each of its item and score, and there is should be a middle value for attitude assessment.

"I was a bit confused yesterday at the teamwork. ... well, we have to learn each of their work that we have not been knew. So I saw the team performance from their practice ... "(Informant 5)

\section{b. The character accompaniment strategy.}

The education of character is very important. Hence, there is should be a strategy that must be done by a preceptor. For example reprimanding when they met the students, checking the students' integrity, and emphasizing the students' empathy skill. To achieve this, it is necessary to 
provide assistance for the students. For example, the students should practicing with preceptors at least three times a week, or add an obligation to pray at the mosque especially for the male students.

TABLE I. THEMES AND SUB-THEMES

\begin{tabular}{|c|c|c|}
\hline & Themes & Sub-Themes \\
\hline \multirow[t]{2}{*}{$\begin{array}{l}\text { Knowledge } \\
\text { Competence }\end{array}$} & $\begin{array}{l}\text { 1. The } \\
\text { Stregthening } \\
\text { of concepts } \\
\text { and problem } \\
\text { analysis }\end{array}$ & $\begin{array}{l}\text { a. The lack of knowledge when } \\
\text { entering the initial phase } \\
\text { b. Strengthening concepts and } \\
\text { problem analysis }\end{array}$ \\
\hline & $\begin{array}{l}\text { 2. The } \\
\text { suitability of } \\
\text { case and } \\
\text { level of } \\
\text { knowledge }\end{array}$ & $\begin{array}{l}\text { a. The number of cases is } \\
\text { sufficient } \\
\text { b. The level of knowledge is } \\
\text { appropriate for general level } \\
\text { nurses }\end{array}$ \\
\hline \multirow[t]{2}{*}{$\begin{array}{l}\text { Skills } \\
\text { competition }\end{array}$} & $\begin{array}{l}\text { 3. } 3 \text {. The } \\
\text { Motivational } \\
\text { support for } \\
\text { action }\end{array}$ & $\begin{array}{l}\text { a. Not enough to dare to act } \\
\text { b. Need the motivation to try }\end{array}$ \\
\hline & $\begin{array}{l}\text { 4. The Sufficient } \\
\text { competency } \\
\text { skills with } \\
\text { various } \\
\text { alternative } \\
\text { learning } \\
\text { systems }\end{array}$ & $\begin{array}{l}\text { a. Alternative learning systems } \\
\text { for skills that have not been } \\
\text { achieved } \\
\text { b. Alternative learning systems } \\
\text { for skills that have been } \\
\text { achieved }\end{array}$ \\
\hline \multirow[t]{3}{*}{$\begin{array}{l}\text { Attitude } \\
\text { competence }\end{array}$} & $\begin{array}{l}\text { 5.The } \\
\text { Leadership } \\
\text { and The } \\
\text { spirituality }\end{array}$ & $\begin{array}{l}\text { a. The students are sociable } \\
\text { b. Collaboration and leadership } \\
\text { c. The aspect of spirituality has } \\
\text { been maintained }\end{array}$ \\
\hline & $\begin{array}{l}\text { 6. The Caring } \\
\text { Action }\end{array}$ & $\begin{array}{l}\text { a. Emphasis on spiritual } \\
\text { intervention } \\
\text { b. Responsive to the situation } \\
\text { c. Empathy and honest }\end{array}$ \\
\hline & $\begin{array}{l}\text { 7. The Efforts } \\
\text { to improve } \\
\text { the affective } \\
\text { quality of the } \\
\text { students }\end{array}$ & $\begin{array}{l}\text { a. The Standardization of } \\
\text { judgment and attitude } \\
\text { b. The character } \\
\text { accompaniment strategy }\end{array}$ \\
\hline
\end{tabular}

\section{DISCUSSION}

Evidence-based developments open up insights for educational institutions, that education especially health begins to pay attention to competency-based approaches so that the outcome to be achieved must be clear [6]. Competency is the ability to demonstrate knowledge, values and skills, which can be integrated into practice [7]. Hence, competency is the interrelation of abilities, including knowledge, skills, and attitudes in various performance domains in certain contexts [8]. Competency-based education and evaluation should meet two conditions, namely clear identification, measurable variables with performance indicator levels, specific skills as needed for professional practice, and evaluation skills through measurable criteria [6].

\section{A. Stregthening the concepts and problem analysis}

Health services in the emergency areas are required to be able to provide care in a fast, appropriate, and quality way [4]. This is a challenge for clinical practice students, considering that the students are still in the process of learning and adapting to their new environment, as well as learning to relate theories and practices in hospitals. The ability to understand concepts and analyze problems well, has an impact on providing care with emergency conditions quickly, precisely and quality under the supervision of the professional nurse. Dal \& Sarpkaya (2013) recommended that training on theory and skills need to be repeated regularly, every 6 months, especially after the students graduated [9].

Nursing students during clinical practice experience anxiety when they first enter the clinic [10]. It caused by a gap between theory and practice, clinical supervision and professional roles that they faced [7][10]. Nursing Study Program UMY has been bridging the integration between theories and practices and students preparation, before entering clinical practice, by gives the students a briefing both by the academic supervisor and by the preceptor. The debriefing material covers the description of cases when practicing in the emergency room and ICU/ ICCU, the learning methods to be undertaken, learning strategies while in the clinic and the minimum achievement targets to be achieved by students at the end of the section. In addition, at the beginning of the section, this debriefing material reflects some points about the concepts of emergency and critical nursing. Thus, the students are expected to have an overview of things that must be prepared before entering clinical practice, especially the emergency nursing department. A nurse must have adequate knowledge and skills because a nurse is should be close to patients for 24 hours. In addition, the effectiveness and timeliness in nurses responding to changes in the patient's condition becomes very important because nurse is the person who provide first detection and aid [9].

Another factor that makes students considered less knowledgeable at the beginning of the phase is the difficulty of transferring knowledge that has been obtained at university to real situations in patients due to different student backgrounds, different learning experiences, different interpersonal communication skills, and interactions with others in the practice field. The students did not have the ability to transfer knowledge automatically in different settings, even though they are equipped with some skills. This ability will developed and be honed by experience and interaction with the real patient's condition [11].

\section{B. Case Suitability and Knowledge Level}

The result of the researches in the realm of knowledge shows that there are many cases of preceptees. The achievement of the cases in professional education such as the handling of resuscitation in patients has often found. The availability of the cases in the professional education practice will provide experiences in handling patients with 
emergency cases that can increase the knowledge and skills of the preseptee to achieve their competency. According to the American Nurse Association (ANA) (2008), it has been explained that knowledge includes thinking, understanding of science and humanities, professional practice standards, and insights gained from practical experience, personal abilities, and leadership performance [12].

The practice of the emergency nursing clinic is different compared to the other sections. The students can encounter frequent cases such as cardiac cases with decreased consciousness, as well as rare cases such as the patients who have a Catena Vein Central (CVC) or even the newest cases to the preseptee, such as the patients with mechanical ventilation. The preceptees in this case are adults who must have the ability to learn (Adult Learning). According to Knowles, there are four different assumptions about adult learning, namely: (1) adults need to know why they are learning, (2) adults are problem solvers, (3) adults learn to do, and (4) adults will learn better if they can directly use their learning materials. Adult learning theory explains that adults learn could be better when they are given a choice, when they are allowed to use self-directed learning as an option when it is available, and finally when they can build and share their experiences [13]

Learning methods that available in professional education have been equipped students to have the ability to learn as adult learning. These learning methods include case-based learning with clinical tutorial activities, conferences, case presentations, and bedside teaching. The learning activities will equip students to improve their critical thinking and clinical reasoning abilities. Some of these activities stimulate students for self-directed learning while attend in the professional education stage.

\section{Motivational support for action}

According to Bandura's self-efficacy theory, it has stated that a person will be able to perform a certain skill if he has a clear outcome to be achieved, as one way to measure competency [14]. In the Big Indonesian Dictionary, it has stated that motivation is an impulse that arises in a person consciously or unconsciously to take an action with a specific purpose. Motivation can also be interpreted as an effort that could caused a person or group of people to do something because they would to achieve the desired goals or get satisfaction with their actions (KBBI).

In this study, it has revealed that to be able to work on an action/kill, students must often to be motivated to try. This is because the ability of each student is different, so the confidence that generated also affects. This motivation is urgently because, based on the conditions in the field/in the hospital where the practice is, the students sometimes seem to be passive when the patients come, and the students confused about what they should to do. This could be caused by several things, for example the ability to recognize and analyze cases that still lack, and the skills for certain types of actions that have not been mastered.

The research from Thomson et al . (2014) stated that a clinical instructors will be enthusiastic in guiding their juniors due to the existence of several motivations, including to update his clinical knowledge by learning new sciences from his juniors. Thomson said that this motivation is the most frequently expressed. Another motivation in educating is feeling satisfy and enjoy as a mentor, as a medium to hone general skills, as a career improvement and as a form of responsibility to the profession and society. Although motivated to educate, there are also obstacles that often discourage the motivation of an instructor, usually because of the fear of losing a lot of time, less compensation that received, administrative costs, and inadequate facilities [15]. The problem of time is a major barrier in the learning process.

The results of this study also provide meaningful input for educational institutions, that to be able to motivate students, the preceptor must also have a positive motivation in educating. The existence of this positive motivation will influence the style of coaching and strategies to accompany students to learn.

The results of the study from Antonescu and Vîrban (2015) prove that vocational students have motivated to take action because they want to be successful, raise performance standards and become the goal-oriented man. Antonescu and Vîrban's research emphasized that the existence of motivation influences the maturity of someone to act [16].

\section{Several alternative learning systems are needed to achieve skills competence}

UMY Nursing Studies Program has implemented a learning model with Problem Based Learning (PBL) in the professional stage. Learning methods are implemented from Bed Side Teaching, Presentation Journals, Case Presentation, DOPS, Mini-CEX and Longcase, which all of those processes derived from case to solve the problem.

According to Westhues et.al. (2014), the implementation of PBL could be a failure due to three factors, namely the involvement of volunteers in the PBL trial, an initial explanation of PBL to orient participants who took up to 15 hours long, and the role of discussion groups and conflict management. This is an effort to take steps so that PBL goals can be achieved [17].

Westhues et.al. (2014) stated that the PBL method is effective in helping students to learn about social work skills, knowledge and values, and is effective in improving the learning of skills that will support students as long-life learners. PBL more emphasizes students as deep learners, so that several learning strategies can be run simultaneously [17].

The results of this study illustrate that the number of cases which must learned by the students is quite a lot and varied. In the same time, performing a particular skill is sometimes still difficult, because these skills are rarely performed. To get around this, several alternative methods are needed so that the target student skills can still be achieved. For example, catheter placement skills can be circumvented by using phantom. In addition, arterial blood sampling is could replaced by analysis of arterial blood results. For some difficult skills, students do not have to do, but could be brought in discussion forums such as case presentations, journal presentations or tutorials.

The results of this study found three themes in the attitudes of students of professional practice, namely: leadership and spirituality, caring, and the importance of 
efforts to improve the quality of attitudes of the nurses. The nurses are expected to be able to quickly adapt and provide leadership spirit to achieve the fulfillment of health consumer demand.

\section{1) Leadership and Spirituality}

In the first theme it was found that UMY nursing students already had leadership and spirituality attitudes. The leadership aspect can be seen in the statement that nursing students are able to work together and have good leadership. Roussel et.al (2018) believes that leadership can be taught. To develop risk-taking behavior and self-confidence, students must be supported so as to be able to create solutions to the problems they face. Another ability that is expected is to be able to debate and be guided not to be afraid of making mistakes. The educational process in the Nurses' Professional Program has facilitated the formation of leadership through the process of clinical tutorials, and case reflection. This is in accordance with Parks (2013) statement in Roussel et.al (2018) that critical thinking and reflection need to be developed to support the formation of a leadership attitude formation process [18].

In addition to leadership, the aspects of student spirituality were also assessed as evidenced by neat clothes and covering the genitals well, keeping the congregational prayer at the mosque to male coners, and to teach the patients about tayammum and pray according to the ability of the patients. The attitudes for the spiritual fulfillment of these patients are in accordance with the vision and mission of UMY and Nursing Study Bachelor Program UMY that form Nursing graduates who excel in clinics and Islam.

\section{2) Caring}

The caring aspect is the second theme found on the students. Most of the students are able to show caring attitude. This can be seen in their responsivity to the surrounding situation, empathy for others, and the honest attitude. The caring attitude of these students is in accordance with the four caring elements according to Tronto (in Lachman, 2012), namely: 1) the attentiveness; 2) the responsiblity; 3) the competentity; and 4) the openness to the patients. However, there are still some students who are judged to be lack in some aspects: discipline and empathy. Based on this case, the students should increase their concern, especially in patients, patients' families and also other health workers. The concern for the patients and their families is the first step in knowing the needs of them. If the nurse fails to do this, then both the patients and their family will not feel the caring aspect from the nurse [19].

The professional nursing education learning strategies, including discussions (conferences), and bed side teaching are considered capable of playing a role in shaping students' behavior. This is according to Heiserman (2016) which stated that learning strategies to form affective domains can be done through individual discussions, group discussions, role playing, and role modeling. The discussion motivates students to participate and get feedback from lecturers either. Moreover, the role playing and role modeling that provided by the lecturers, will encourage the students' desire to participate in learning activity [20]. Therefore, the preceptorship model used in the professional education program of Nursing Study Program of UMY, where the prcseptee always follows the preceptor in the way to forming the preseptee's attitude.

3) Efforts to Improve the Quality of Affective Students

The third theme that found is an effort to improve the affective quality of students. Preceptor assesses that there is still a need to improve standards in assessing students' attitudes. The current assessment format generally produces good points, and there is no middle value. Therefore, it is urgently to have an assessment which easy to translated and to identify the aspects that measured. The nursing education need to change their education system in order to become lifelong learners and demonstrate ongoing clinical competence.

Affective domains in the area of emergency nursing based on Harding et.al (2013) are expecting the nurses to be: 1) open to the patient complaints; 2) easy to help; and 3) objectively and respectfully in caring patients. The nurses have a duty to the public interests, to their profession and also to preserve their career by show their competence. An increasing number of patients through the emergency unit, encouraged the nurses in the emergency nursing to maintain their competence [13].

\section{CONCLUSION}

The results of this study provide one main theme, namely strategy and learning reinforcement. It consists of two themes for the knowledge realm, two themes for the skills realm and three themes for attitudes realm.

Suggestion: It is urgently to have a strategy and reinforcement of learning, specifically in the knowledge, skills and attitudes realm in the Nursing Study Program of UMY to achieve the nurses competence in the Emergency Nursing Stage. It is urgently either to have a strategy and strengthening the guidance process at the time of the preceptee's clinical practice in the emergency nursing stage in the Nursing Study Program of UMY.

\section{ACKNOWLEDGMENT}

We said thansk you to all clinical preceptors in PKU Muhammadiyah Yogyakarta Hospital, PKU Muhammadiyah Gamping Hospital, PKU Muhammadiyah Temanggung Hospital.

\section{REFERENCES}

[1] L.A. Snell and F.M. Daniels. Perceptions of professional nurses regarding clinical competence of community service practitioners from degree and diploma programmes offered in the Western Cape. African Journal for Physical, Health Education, Recreation and Dance (AJPHERD), Suplement 1(1), pp. 142-153. 2014.

[2] Kubin, L., and Fogg, N. Back-to-basic boot camp: An innovativeapproach to competency assessment. Journal of pediatric nursing, $25, \quad$ pp. $28-32$. http://dx.doi.org/10.1016/j.pedn.2008.07.004. 2010.

[3] Janelle L. Theisen, MA, RN, and Kristin E. Sandau, PhD, RN, CNE. Competency of new graduate nurses: a review of their weaknesses and strategies for success. The journal of continuing education in nursing, 44(9), pp. 406-414. 2013.

[4] Holanda FL, Marra CC, Cunha IC. Professional competency profile of nurses working in emergency services. Acta Paul Enferm, 28 (4), pp. 308-3014. 2014.

[5] Farell S.E. Evaluation of student performance: clinical and professional performance. Acad Emerg Med, 12(4), pp. 6-10. 2005. 
[6] Damron-Rodriguez, J. A., \& Effros, R. Innovations in studentcentered teaching for general education in aging. Gerontology and geriatric education. 29(3), pp. 270-89. 2008.

[7] Kholofelo L. Matlhaba, Abel J. Pienaar, Leepile A. Sehularo. Community service nurses' experiences regarding their clinical competence. Health SA gesondheid, 24, pp. 1-8. 2019.

[8] Riddle, Beker, Shapp. Evaluation of testing as a method to assess continued competency in nurse anesthesia practice: a systematic review. AANA Journal, 84 (4), pp. 239-45. 2016.

[9] Dal U \& Sarpkaya D. Knowlege and psychomotor skills of nursing students in North Cyprus in the area of cardiopulmonary resuscitation. Pak J Med Sci, 29 (4), pp. 966-971. 2013.

[10] Farkhondeh Sharif and Sara Masoumi. A qualitatif study in nursing student experiences of clinical practice. BMC Nursing, 4(6), pp. 1-7. 2005.

[11] Mona Ewertsson, Sangeeta Bagga-Gupta, Renée Allvin, Karin Blomberg. Tensions in learning professional identities-nursing students' narratives and participation in practical skills during their clinical practice: an ethnographic study. BMC Nursing, 16(48), pp. 18. 2017.

[12] American Nurses Association. Professional role competence. Silver Spring, Maryland, 2008.

[13] Harding, A.D., Cillo, G,E,W., Duke, A., Campos, G,J., Stapleton, S.J. A framework for creating and evaluating competencies for emergency nurses. Journal of emergency nursing, 39(3), pp. 252-264. 2013.
[14] Bandura, A. Self efficacy-the exercise of control. New York, W.H. Freeman \& Company, 1997.

[15] Thomson, Jennifer, Emily Haesler, Katrina Anderson, and Amanda Barnard. What motivates general practitioners to teach. Clinical teacher, 11 (2). Pp. 124-30. http://10.0.4.87/tct.12076. 2014.

[16] Antonescu, Florin Marian, and Petronela Sorina Vîrban. Relationship motivation-vocational maturity to students to practice sports contact. Proceedings of the scientific conference AFASES 1 (May). Henri Coanda Air Force Academy, pp. 153-57. http://search.ebscohost.com/login.aspx?direct=true \&db=a9h\&AN=10 8556571\&site=ehost-live. 2015.

[17] Westhues, Anne, Chia Barsen, Nancy Freymond, and Patricia Train. An outcome evaluation of a problem-based learning approach with MSW students. Journal of social work education, 50(3), pp.472-89. http://10.0.4.56/10437797.2014.917897. 2014.

[18] Roussel, L., Thomas, P.L., \& Ratcliffe, C. Leadership theory and application for nurse leaders. Retrieved from http://samples.jbpub.com/9781284067620/Sample_CH02_Roussel7e. pdf, 2018.

[19] Lachman, V.D. Applying the ethics of care to your nursing practice. MEDSURG nursing, 21(2), pp. 112-116. 2012.

[20] Nicholas Heiserman. The effect of economic inequality on perceptions of merit. Retrieved from https://scholarcommons.sc.edu/etd/3880, 2016. 